\title{
EI-NINO DAN PENGARUHNYA TERHADAP CURAH HUJAN DI MANADO SULAWESI UTARA
}

\author{
Seni Herlina J. Tongkukut ${ }^{1)}$ \\ ${ }^{1)}$ Program Studi Fisika FMIPA Universitas Sam Ratulangi, Manado 95115
}

\begin{abstract}
ABSTRAK
Telah dilakukan analisis El-Nino dan pengaruhnya terhadap curah hujan di Manado Sulut dengan menggunakan data curah hujan bulanan dan Southern Oscillation Index SOI selama thn 19992009. Data curah hujan diperoleh dari BMKG Kayuwatu Manado Sulut dan data SOI diunduh dari website Biro Meteorologi Australia BoM. Analisis dilakukan dengan analisis regresi linear sederhana. Diperoleh hasil bahwa curah hujan kota Manado secara umum dari thn 1999-2008 dipengaruhi oleh SOI namun pada thn 2009 ketika terjadi El-nino, curah hujan bulanan Manado tidak dipengaruhi oleh efek El-nino. Hal ini karena pada saat yang sama suhu muka laut perairan Indonesia juga menghangat.
\end{abstract}

Kata kunci: Curah hujan, SOI.

\section{EL-NINO AND ITS EFFECT ON RAINFALL IN MANADO NORTH SULAWESI}

\begin{abstract}
Analysis of El-Nino and its effect on rainfall in Manado, North Sulawesi, using monthly rainfall data and the Southern Oscillation Index SOI during the years 1999-2009 has been carried out. Rainfall data obtained from BMKG Kayuwatu Manado and SOI data downloaded from the website of Australian Bureau of Meteorology (BoM). The analysis was performed with simple linear regression analysis. The results obtained indicate that rainfall in Manado, in general, was influenced by SOI from the years 1999-2008, but when there is an El-Nino in 2009, monthly rainfall in Manado is not affected by the El-Nino effect. This is due to, at the same time, sea surface temperature in Indonesian territory are also warm.
\end{abstract}

Keywords: rainfall, SOI

\section{PENDAHULUAN}

El-Nino merupakan salah satu gejala alam yang dapat mempengaruhi iklim secara global. El-Nino sendiri berarti anak laki-laki dan peristiwa ini teramati oleh nelayan Peru pada bulan Desember berupa menghangatnya suhu lautan di wilayah Amerika Selatan, dekat Equador yang meluas hingga perairan Peru. El-Nino adalah peristiwa yang tidak normal berupa pemanasan permukaan air laut di laut Pasifik Tropis bagian Timur.

Permukaan laut yang lebih panas menyebabkan tekanan udara permukaan diatasnya menjadi lebih rendah. Ketika laut tropis bagian timur memanas, laut tropis bagian barat akan menjadi lebih dingin sehingga tekanan udara permukaan diatasnya menjadi lebih tinggi. Demikian sebaliknya yang kemudian membentuk pola osilasi yang dikenal sebagai osilasi selatan atau southern oscillation (Ahrens,2007). Indeks osilasi selatan atau SOI (Southern Oscillation Index) merupakan suatu nilai yang menunjukkan telah terjadi peristiwa El-Nino atau tidak. Indeks Osilasi Selatan menyatakan perbedaan antara tekanan atmosfir di atas permukaan laut di Tahiti (Pasifik Timur) dengan tekanan atmosfir diatas permukaan laut di Darwin (Pasifik Barat) akibat perbedaan temperatur muka laut di kedua wilayah tersebut. Apabila nilai Indeks Osilasi Selatan berada pada harga minus dalam jangka waktu 3 bulan berturut-turut maka telah terjadi El-nino. 
Semakin negatif semakin kuat kejadian panas. Menurut pengamatan El-nino berulang dalam rentang 2 sampai 7 tahun atau rata-rata terjadi empat tahun sekali (Sarachik, 2010).

El-nino sebagai fenomena lautan dan atmosfer skala global akan mempengaruhi sirkulasi atmosfir skala regional dan skala lokal. Angin sebagai bentuk pergerakan udara, akan bergerak dari daerah bertekanan tinggi ke daerah bertekanan rendah. Pada saat El-nino terjadi, angin akan cenderung bergerak menuju Pantai Barat Peru di Pasifik Timur yang bertekanan udara rendah. Pergerakan angin yang merupakan faktor penting dalam pembentukan pola curah hujan di suatu tempat, secara langsung akan terpengaruh. Pada thn 1995 El-nino telah menyebabkan kondisi kekeringan di Afrika dan Australia. Kepulauan Indonesia yang terletak pada $7^{\circ} \mathrm{LU}-12^{\circ} \mathrm{LS}$ dan $94^{\circ} \mathrm{BT}$ $142^{\circ} \mathrm{BT}$ merupakan daerah yang berada di equator dan berbatasan dengan Laut Pasifik di bagian Timurnya. Letak geografis ini mengakibatkan jika terjadi El-nino, Indonesia akan dapat merasakan dampaknya. Pada thn 1997/1998 El-nino telah menyebabkan kekeringan di beberapa wilayah Indonesia.

BMKG Jakarta Indonesia pada bln Juli 2009 telah memprediksi akan terjadi El-nino pada tahun 2009. Demikian juga Biro Meteorologi Australia BoM (Bureau of Meteorology). Menurut BMKG Jakarta pada Juli hingga Agustus 2009 El-nino masuk kategori lemah, September, Oktober dan Desember 2009 berkategori sedang dan November serta Desember 2009 sampai Januari 2010 El-nino mencapai kategori kuat. Menurut BoM sejak Agustus 2009 hingga Februari 2010 El-Nino berkategori sedang. BMKG juga menyatakan daerah Indonesia yang berpotensi terpengaruh El-nino adalah kawasan Indonesia bagian tengah dan timur ( BMKG, 2009)

Berdasar prediksi tersebut dan Indeks Osilasi Selatan thn 2009, akan dianalisis pola curah hujan di Manado thn 2009 akibat pengaruh El-Nino.

\section{TINJAUAN PUSTAKA}

\section{El-Nino}

El-Nino merupakan fenomena alam yang secara ilmiah diartikan dengan meningkatnya suhu muka laut atau SST (Sea
Surface Temperature) di sekitar Pasifik Tengah dan Timur sepanjang ekuator dari nilai rata-ratanya. Pada tahun-tahun normal, suhu muka laut di sebelah Utara dan Timur Laut Australia bernilai $\geq 28^{\circ} \mathrm{C}$ sedangkan suhu muka laut di Samudra Pasifik sekitar Amerika Selatan bernilai $\pm 20^{\circ} \mathrm{C}$.

Pada keadaan normal, air laut dalam yang bersuhu rendah dan kaya nutrisi bergerak naik ke permukaan laut di wilayah dekat pantai yang dikenal sebagai upwelling di wilayah pantai Amerika Selatan, dekat Equador dan meluas hingga ke Perairan Peru. Pada kondisi normal tersebut, angin permukaan di wilayah Samudra Pasifik di sekitar equator yang dikenal sebagai Angin Pasat Timuran (Walker Circulation) dan air laut di bawahnya mengalir dari Timur ke Barat (Ahrens, 2007). Arah aliran ini sedikit berbelok ke utara pada Bumi Belahan Utara dan ke Selatan pada Bumi Belahan Selatan. Pada keadaan ini penguapan di Samudra Pasifik akan secara nyata meningkatkan kelembaban udara di atasnya sehingga Angin Pasat Timuran menyebabkan daerah yang berpotensi tumbuh awan-awan hujan adalah di Samudra Pasifik Barat, wilayah Indonesia dan Australia Utara.

Pada saat El-Nino terjadi, suhu muka laut di Pasifik Timur Ekuator lebih tinggi dibanding nilai rata-ratanya. Jumlah air laut bersuhu rendah yang mengalir di sepanjang Pantai Selatan Amerika dan Pasifik timur berkurang bahkan menghilang samasekali. Akibat suhu yang lebih tinggi, tekanan udara di atas permukaan laut menjadi rendah hingga udara cenderung bergerak naik dan turun dikawasan yg lebih dingin seperti yang nampak pada gambar 1 .

Gambar 1. Memperlihatkan suhu muka laut diperairan Pasifik Barat yang lebih dingin menyebabkan tekanan udara di atasnya menjadi tinggi dan udarapun cenderung bergerak turun lalu bergerak ke daerah dengan tekanan lebih rendah artinya di atas permukaan laut di Pasifik Barat equator angin akan bergerak ke timur (Sarachik, 2010). Hal ini menyebabkan massa udara yang mengandung uap air di atas Australia, Indonesia dan sekitarnya akan terdorong ke timur sehingga secara langsung akan mengurangi potensi hujan.

Angin Monsoon adalah angin yang berhembus secara periodik setiap enam bulan dengan arah yang saling berlawanan. Pada 

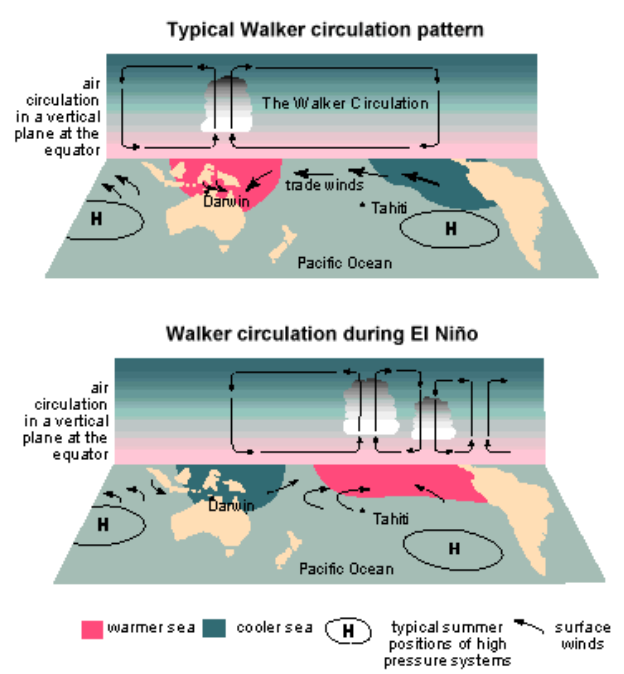

Gambar 1. Pola Sirkulasi Walker Keadaan Normal Dan Keadaan El-Nino

bulan Oktober-April, matahari berada di belahan bumi selatan sehingga Benua Australia mengalami musim panas. Pada saat ini tekanan udara di atas Australia bernilai minimum sedangkan tekanan di atas Benua Asia yang lebih dingin sedang maksimim. Akibatnya angin akan bergerak dari Asia ke Australia. Angin yang melewati Samudra Pasifik dan Laut Cina Selatan ini lalu disebut angin Monsoon Asia, banyak membawa uap air sehingga berpotensi menurunkan hujan di Indonesia dan Malaysia. Keadaan sebaliknya adalah angin Monsoon Australia yang menyebabkan musim kemarau di Indonesia karena massa udara yang bergerak dari Australia ke Asia sedikit membawa uap air karena melewati gurun pasir di utara Australia dan hanya melewati laut yang sempit. Ketika El-Nino terjadi, angin Monsoon Asia yang seharusnya melewati Indonesia akan tertarik dan berbelok ke Pasifik Tengah karena tekanan di kawasan tersebut yang sedang turun. Sehingga dikatakan sirkulasi Monsoon melemah.

Secara umum ketika terjadi El-Nino:

- Angin Pasat Timuran melemah artinya angin berbalik arah ke Timur dan mendorong wilayah potensi hujan ke timur. Hal ini menyebabkan perubahan pola cuaca. Daerah potensi hujan meliputi wilayah Perairan Pasifik Tengah dan Timur dan Amerika Tengah.

- Sirkulasi Monsoon melemah

- Akumulasi curah hujan berkurang di wilayah Indonesia, Amerika Tengah dan Amerika Selatan bagian Utara
- Potensi hujan terdapat di sepanjang Pasifik Ekuatorial Tengah dan Timur serta wilayah Argentina.

Kekuatan setiap El-Nino tidak selalu sama. Intensitasnya dikategorikan menurut besarnya penyimpangan suhu muka laut yang menyebabkan perubahan tekanan udara diatasnya dari nilai rata-ratanya. Perubahan tekanan udara tersebut terbaca melalui Indeks Osilasi Selatan yang menyatakan semakin negatif nilai SOI semakin kuat intensitas ElNino. Adapun kategori intensitas El-Nino adalah (salmawati 2010):

- El-Nino lemah jika indeks SOI -5 s/d 0 dan berlangsung minimal 3 bulan berturutturut

- El-Nino sedang jika indeks SOI -10 s/d -5 dan berlangsung minimal 3 bulan berturutturut

- El-Nino kuat jika indeks SOI >-10 dan berlangsung minimal 3 bulan berturutturut

\section{Curah Hujan}

Hujan adalah salah satu bentuk presipitasi. Tjasyono (2008) mendefinisikan presipitasi sebagai pengendapan air dari atmosfir pada permukaan bumi dalam bentuk cair (tetes hujan) dan padat (salju). Di wilayah tropis seperti Indonesia presipitasi lebih didefinisikan sebagai hujan karena sangat jarang terjadi presipitasi dalam bentuk jatuhan keping es.

Jumlah curah hujan dicatat dalam inci atau millimeter. Jumlah curah hujan $1 \mathrm{~mm}$ menunjukkan tinggi air hujan yang menutupi permukaan bumi yang datar seluas $1 \mathrm{~m}^{2}$ jika air tersebut tidak meresap ke dalam tanah atau menguap ke atmosfir (Tjasyono, 2004). Tinggi curah hujan diasumsikan sama di sekitar tempat penakaran dengan luasan yang tercakup oleh sebuah penakar hujan tergantung pada homogenitas daerahnya.

Curah hujan mempunyai variabilitas yang besar dalam ruang dan waktu. Dalam skala ruang, variabilitasnya sangat dipengaruhi oleh letak geografi, topografi, arah angin dan letak lintang. Dalam skala waktu keragaman curah hujan dibagi atas tipe harian, bulanan dan tahunan. Variasi curah hujan harian lebih dipengaruhi oleh faktor lokal, variasi bulanan dipengaruhi oleh angin darat dan angin laut, aktivitas konveksi, arah aliran udara di permukaan serta variasi 
sebaran daratan dan lautan. Variasi curah hujan tahunan dipengaruhi oleh perilaku atmosfir global, siklon tropis dan lain-lain (Prasetya, 2011)

Secara umum curah hujan di Indonesia didominasi oleh pengaruh beberapa fenomena seperti sistem monsoon AsiaAustralia, El-nino, sirkulasi Timur-Barat (Walker Circulation) dan Utara-Selatan (Hadley Circulation) serta beberapa sirkulasi karena faktor lokal (Prasetya, 2011). Cuaca permukaan wilayah Indonesia relatif sama. Massa udara di atas wilayah Sulawesi pada waktu Monsoon Asia berasal dari Laut Cina Selatan dan Pasifik Barat Daya. Pada waktu Monsoon Asia melemah, potensi hujanpun akan menurun.

\section{METODOLOGI PENELITIAN}

Penelitian ini dilaksanakan di Lab. Geofisika Jurusan Fisika FMIPA Unsrat dan Badan Meteorologi, Klimatologi dan Geofisika Kayuwatu Manado. Metode penelitian meliputi studi literatur, pengambilan data curah hujan wilayah Manado thn 1999-2009 dari BMKG Kayuwatu dan mengunduh data SOI thn 1999-2009 dari website Biro Meteorologi Australia BoM. Data SOI dan data curah hujan 1999-2008 dianalisis dengan analisis regresi linear sederhana untuk mengetahui hubungan kedua variabel tersebut. Selanjutnya data curah hujan Manado thn 2009 dan SOI thn 2009 dianalisis dengan analisis regresi linear sederhana untuk melihat pengaruh fenomena El-Nino pada curah hujan Manado thn 2009.

\section{HASIL DAN PEMBAHASAN}

Indeks osilasi selatan atau Southern Oscillation Index (SOI) dihitung serta dipublikasikan secara rutin antara lain oleh Bureau of Meteorology BoM yaitu Biro Meteorologi Australia. Penelitian ini menggunakan SOI bulanan dari BoM Australia untuk tahun 1999-2009.

Data SOI menurut BoM (2011) untuk rentang waktu selama sepuluh tahun yaitu thn 1999-2008, diolah dengan cara dirataratakan untuk bulan yang sama dan hasilnya ditunjukkan seperti pada Gambar 2.

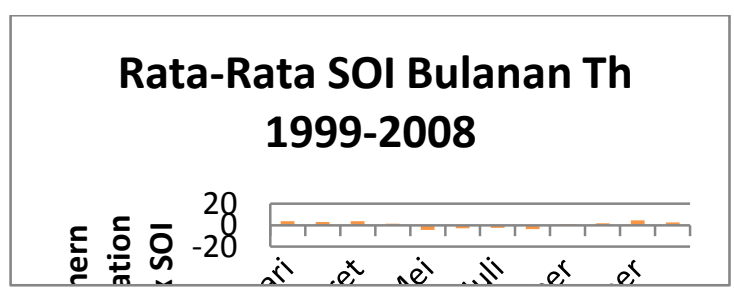

Gambar 2. Rata-rata SOI bulanan Thn 19992008

Gambar 2 Menunjukkan secara umum SOI negatif sebagai penanda El-Nino mulai terdeteksi pertengahan tahun. Pada tahuntahun El-nino, SOI akan bernilai negatif sampai akhir tahun.

Secara teori, El-nino yang ditandai oleh indeks osilasi selatan yang negatif akan mengurangi curah hujan antara lain di Indonesia. Sulawesi Utara yang relatif lebih dekat ke Samudra Pasifik dan berada dekat dengan equator, curah hujannya tentu akan dipengaruhi oleh fenomena El-nino. Untuk mengetahui hubungan atau pengaruh El-nino terhadap curah hujan di Manado, curah hujan $(\mathrm{CH})$ dan SOI sebagai penanda El-nino akan dianalisis dengan analisis regresi linear sederhana. Hasil analisa akan menunjukkan ada atau tidaknya hubungan kedua variabel tersebut (Sunyoto, 2009).

Untuk keperluan analisis hubungan SOI dan curah hujan, curah hujan bulanan Manado selama sepuluh tahun yaitu thn 1999-2008 dirata-ratakan untuk bulan yang sama seperti pada SOI. Curah hujan bulanan rata-rata tersebut ditunjukkan seperti pada Gambar 3.

\section{Curah Hujan Bulanan Rata- Rata Kota Manado Th 1999-2008}

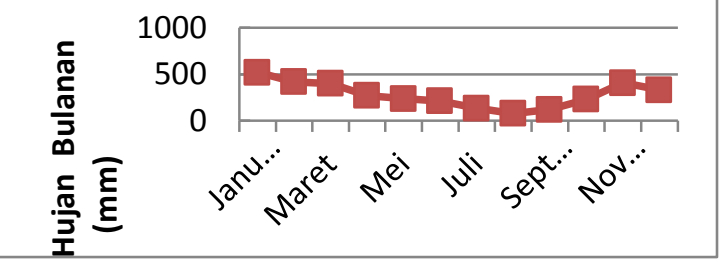

Gambar 3. Curah Hujan Bulanan Rata-rata Manado Thn 1999-2008

Gambar 3. menunjukkan Manado mengalami musim hujan dan musim kemarau 
setiap tahunnya. Curah hujan diatas normal atau musim hujan lebih lama yaitu sekitar bulan Oktober sampai Mei dan musim kemarau atau curah hujan dibawah normal pada sekitar bulan Juni-September.

Hubungan variabel SOI dan curah hujan rata-rata selama sepuluh tahun seperti tersebut diatas, dianalisis dengan analisis regresi linear sederhana dengan SOI rata-rata sebagai variabel bebas (x) dan curah hujan rata-rata sebagai variabel bergantung (y). Persamaan regresi yang diperoleh adalah $\mathrm{y}=$ $253,4+32,1 x$. Persamaan regresi ini mempunyai koefisien korelasi $\mathrm{r}$ sebesar 0,78. Dengan taraf signifikan $10 \%$ hipotesa bahwa SOI rata-rata mempengaruhi curah hujan rata-rata adalah benar meskipun hanya pada tingkat cukup kuat. Hal ini berarti bahwa fenomena El-nino juga mempengaruhi curah hujan di Manado.

Persamaan regresi yang telah diperoleh, selanjutnya digunakan untuk menentukan atau memprediksi curah hujan bulanan ratarata Manado selama thn 1999-2008. Dengan menggunakan SOI rata-rata sebagai variable $\mathrm{x}$, variabel y yang diperoleh adalah curah hujan bulanan rata-rata prediksi. Hasil yang diperoleh disajikan dalam bentuk grafik seperti pada Gambar 4. yang dibandingkan dengan curah hujan bulanan rata-rata hasil pengamatan pada tahun yang sama.

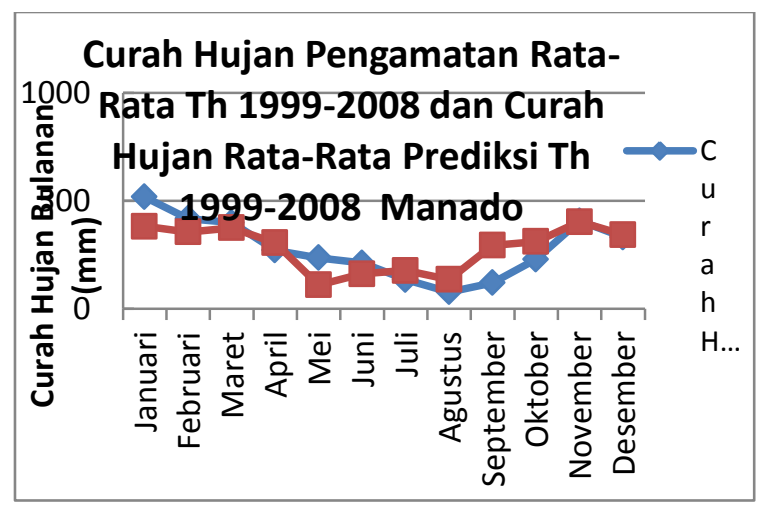

Gambar 4. Curah Hujan Pengamatan Ratarata thn 1999-2008 dan Curah Hujan

Rata-rata Prediksi Thn 1999-2008 Manado

Gambar 4. menunjukkan bahwa curah hujan hasil prediksi dan curah hujan hasil pengamatan memiliki kecenderungan perubahan yang sama. Meskipun pada banyak titik (bulan) nilai curah hujan prediksi tidak tepat sama dengan pengamatan, hal ini disebabkan oleh adanya faktor-faktor selain
El-Nino yang turut mempengaruhi besarnya nilai curah hujan.

Dengan kenyataan bahwa fenomena Elnino telah nyata turut mempengaruhi curah hujan di Manado, selanjutnya curah hujan Manado pada thn 2009 akan dianalisis dengan memanfaatkan SOI sebagai faktor yang mempengaruhinya. Analisis dilakukan untuk mengetahui apakah El-nino sebagaimana yang diprediksi oleh BMKG Jakarta dan BoM Australia yang akan terjadi pada thn 2009 benar-benar mempengaruhi curah hujan Manado pada thn 2009.

Indeks osilasi selatan SOI thn 2009 menurut BoM (2011) adalah seperti pada Gambar 5.

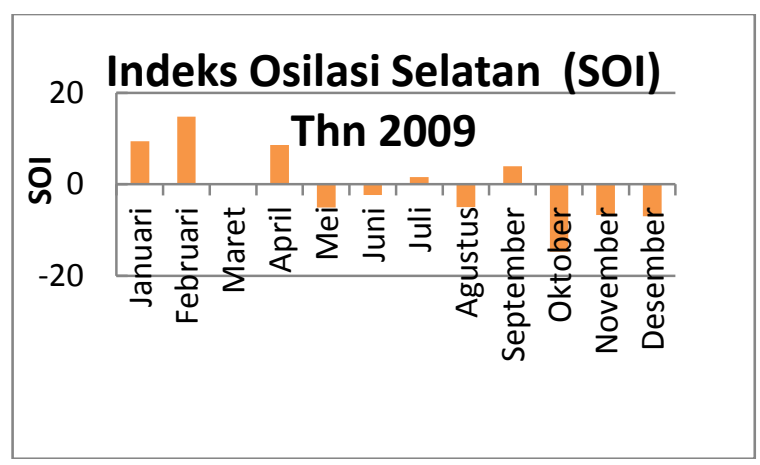

Gambar 5. Indeks Osilasi Selatan Thn 2009

Gambar 5. Menunjukkan bahwa SOI mulai negatif pada bulan Mei tapi kembali positif pada Juli dan September. Namun seterusnya SOI benar-benar negatif selama 3 bulan berturut-turut. Hal ini menunjukkan fenomena El-nino telah terjadi di Lautan Pasifik.

Selanjutnya curah hujan bulanan Manado pada thn 2009 ditunjukkan pada Gambar 6. yang dibandingkan dengan curah hujan bulanan rata-rata selama sepuluh tahun sebelumnya untuk melihat apakah lebih tinggi atau lebih rendah. 


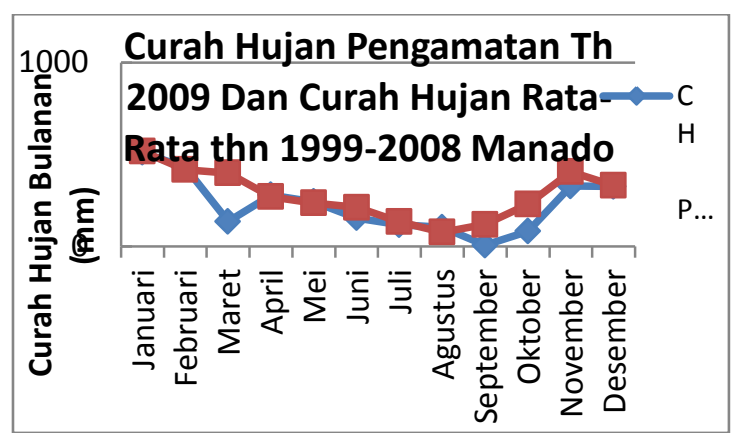

Gambar 6. Curah Hujan Pengamatan thn 2009 dan Curah Hujan Rata-Rata

Tahun 1999- 2008 Manado

Gambar 6. Menunjukkan curah hujan bulanan pengamatan thn 2009 Manado berada pada taraf lebih rendah dari rata-rata sepuluh tahun sebelumnya. Apakah penurunan ini karena pengaruh El-nino pada thn 2009, hal ini harus dianalisis dahulu korelasi antara curah hujan thn 2009 dan SOI thn 2009. Kedua variabel dianalisis dengan analisis regresi linear sederhana dan memberikan persamaan regresi $\mathrm{y}=228,8+$ 8,52x dengan koefisien korelasi 0,46. Koefisien ini menyatakan korelasi yang rendah antara SOI dan curah hujan Manado thn 2009.

Jika SOI thn 2009 digunakan sebagai variabel $\mathrm{x}$ pada persamaan regresi yang diperoleh, maka diperoleh variabel y sebagai curah hujan prediksi karena pengaruh El-nino thn 2009 Manado. Hasil prediksi tersebut disajikan dalam bentuk grafik bersama dengan curah hujan pengamatan thn 2009 Manado seperti pada Gambar 7.

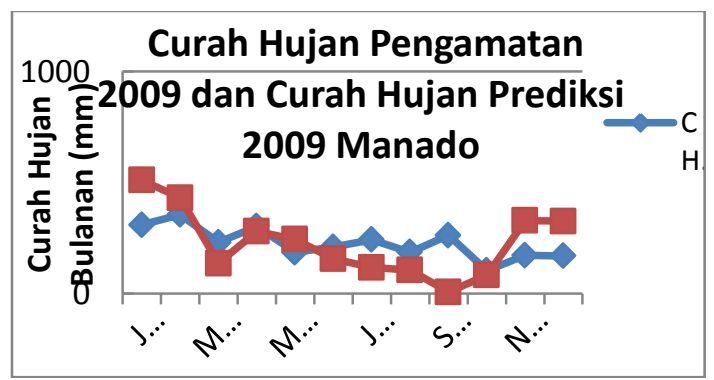

Gambar 7. Curah Hujan Pengamatan dan Curah Hujan Prediksi thn 2009 Manado

Gambar 7. Menunjukkan bahwa pola perubahan curah hujan prediksi dan pengamatan thn 2009 Manado tidak menunjukkan kecenderungan pola perubahan yang sama terutama sejak bulan Mei. Ketika curah hujan prediksi menunjukkan pola yang naik curah hujan pengamatan malah menunjukkan pola yang turun. Ketika prediksinya turun, pengamatannya malah naik. Hal ini menunjukkan bahwa curah hujan Manado thn 2009 meskipun bernilai dibawah rata-rata sepuluh tahun sebelumnya, tetapi bukan karena pengaruh fenomena Elnino meskipun El-nino telah benar terjadi.

Efek El-nino yang tidak berpengaruh pada curah hujan di Indonesia khususnya Manado hanya mungkin jika terdapat faktor yang menghalangi efek El-nino. Ketika Elnino mulai terdeteksi pada Agustus 2009, seharusnya akan diikuti oleh penurunan curah hujan di wilayah Indonesia khususnya Manado karena massa udara yang mengandung uap air akan mengalir ke Pasifik Tengah akibat suhu muka laut di Perairan Indonesia yang mendingin di saat El-nino.

Menurut Ikawati (2010), pada bulan Juli hingga Desember 2009 suhu permukaan laut Indonesia tetap hangat sehangat suhu muka laut di Pasifik Tengah. Akibatnya tidak ada aliran massa udara ke Pasifik Tengah dan uap air yang dibawa angin Monsoon tetap membawa hujan di Indonesia khususnya Manado. Dengan kata lain suhu muka laut perairan Indonesia telah berfungsi sebagai pengendali El-nino. Menghangatnya suhu muka laut perairan Indonesia sendiri merupakan anomali dari keadaan normal yang terlihat sejak Juli 2009 dan diperkirakan disebabkan oleh pemanasan global (Ikawati,Y., 2010).

Curah hujan bulanan thn 2009 yang berada dibawah rata-rata sepuluh tahun sebelumnya dapat disebabkan olef faktor antara lain siklon tropis. Menurut Prasetya (2011) pada 22 sampai 25 Juni 2009 telah terjadi siklon tropis Nangka yang telah menurunkan curah hujan di Manado, 27 September hingga 14 Oktober 2009 telah terjadi siklon tropis Parma yang masa tumbuh hingga dewasanya juga telah menurunkan curah hujan dan 21 November sampai 3 Desember telah terjadi siklon tropis Nida yang masa tumbuh dan punahnya juga telah menurunkan curah hujan. Peristiwa siklon tropis tersebut adalah salah satu faktor yang saat terjadinya telah menurunkan curah hujan di Manado thn 2009. 


\section{KESIMPULAN}

Curah hujan di Manado selama thn 1999-2008 secara umum dipengaruhi oleh nilai Southern Oscillation Index SOI. Namun demikian ketika terjadi El-nino pada akhir thn 2009, curah hujan bulanan pada saat yang sama tidak nampak dipengaruhi oleh efek Elnino dalam arti curah hujan tidak mengalami penurunan karena El-nino. Hal ini disebabkan oleh suhu permukaan laut perairan Indonesia yang tetap hangat saat El-nino terjadi sehingga tidak ada aliran masa udara ke Laut Pasifik.

\section{DAFTAR PUSTAKA}

Ahrens, D. 2007. Meteorologi Today An Introduction To Weather, Climate and The Environment. Thompson Higher Education USA.

BMKG. 2009. Materi Konferensi Pers Prediksi El-nino oleh Institusi Internasional dan BMKG, www.bmkg.go.id. [10 Agustus 2009].
BoM. 2011. Southernern Oscillation Index, www. bom.gov.au. [20 Januari 2011]

Prasetya, R. 2011. Analisis Curah Hujan Akibat Siklon Tropis Nangka, Parma dan Nida di Sulawesi Utara. Skripsi Sarjana FMIPA Unsrat.

Sunyoto, D. 2009. Analisis Regresi dan Uji Hipotesis. Media Pressindo, Yogyakarta.

Salmawati. 2010. Studi Pengaruh Indeks Osilasi Selatan sebagai Indikator ElNino terhadap curah hujan di Sulawesi Utara. Skripsi Sarjana FMIPA Unsrat.

Sarachik, E.S dan M.A. Cane. 2010. The El-Nino Southern Oscillation Phenomenon. Cambridge University Press, USA.

Tjasyono, B.H.K. 2008. Meteorologi Terapan. ITB Bandung.

Tjasyono, B.H.K. 2004. Klimatologi. ITB Bandung.

Ikawati, Y. 2010. Anomali Capai Tingkat Ekstrim, www. sains.kompas.com [10 Febuari 2011]. 